\title{
How Does Indonesian Scientific Production on Renewable Energy Successfully Support the Policy Design? A Journey Towards Sustainable Energy Transition
}

\section{W jaki sposób rozwój indonezyjskiej nauki w zakresie odnawialnych źródeł energii skutecznie wspiera projektowanie polityki? Podróż w kierunku zrównoważonej energetyki}

\author{
Iqbal Akbar ${ }^{\star}$, Dhandy Arisaktiwardhana*, ${ }^{\star \star}$, Prima Naomi ${ }^{\star \star \star}$ \\ *Technische Universität Berlin, Chair of Innovation Economics, \\ Straße des 17. Juni 135, 10623, Berlin, Germany \\ **National Standardization Agency of Indonesia (BSN), Directorate of Laboratory Accredita- \\ tion, Jl. M.H. Thamrin No.8, 10340, Jakarta Pusat, Indonesia \\ ***Universitas Paramadina, Faculty of Business \& Economics, Jl. Gatot Subroto Kav. 97, \\ 12790, Jakarta, Indonesia \\ E-mail (corresponding author): iqbal133@ieee.org
}

\begin{abstract}
The aim to achieve the target of a $23 \%$ share of sustainable energies in the total Indonesia's primary energy supply requires enormous amounts of works. Indonesia's scientific knowledge production can support a successful transition to renewables. However, policy makers struggle to determine how the transition benefits from the scientific production on renewable. A bibliometric study using scientific publication data from the Web of Science (WoS) is used to probe how Indonesian scientific knowledge production can support the policy design for transition to sustainable energy. The seven focused disciplines are geothermal, solar, wind, hydro, bio, hybrid, and energy policy and economics. Based on the data from the above-listed disciplines, a deeper analysis is conducted, and implications to the policy design are constructed. The study reveals that bio energy is the focus of the research topics produced in Indonesia, followed by solar and hydro energy. Most RE research is related to the applied sciences. The innovation capability in the form of technology modifiers and technology adapters supports the transition to sustainable energy in Indonesia. The research on bio energy, however, is characterized by higher basic knowledge than research on solar and hydro energy. This suggests low barriers to the access to the resources and to the completion of bio research in Indonesia. Designing Indonesian energy policy by comprising discriminatively specific sustainable energy sources in the main policy instruments can therefore accelerate the sustainable transition and development.
\end{abstract}

Key words: bibliometrics, sustainable energy, Indonesia, energy policy

\section{Streszczenie}

Cel polegający na osiągnięciu 23\% udziału odnawialnych źródeł energii w całkowitym zaopatrzeniu Indonezji w energię pierwotną jest bardzo trudnym zadaniem. Rozwój wiedzy naukowej może pomóc w pomyślnej jego realizacji. Decydenci mają jednak trudności z ustaleniem, jak wiele w tym procesie faktycznie zależy od nauki. Badanie bibliometryczne, z wykorzystaniem danych o publikacjach naukowych z bazy Web of Science (WoS), pozwalają wykazać, w jaki sposób rozwój indonezyjskiej wiedzy naukowej może wesprzeć projekt polityki przejścia na zrównoważoną energię. Siedem ukierunkowanych dyscyplin to polityka geotermalna, słoneczna, wiatrowa, 
wodna, bio-, hybrydowa oraz energetyczna i ekonomiczna. Na podstawie danych z wyżej wymienionych dyscyplin przeprowadzana jest głębsza analiza i konstruowane są implikacje dla polityki. Okazuje się, że bioenergia jest głównym przedmiotem badań prowadzonych w Indonezji, a następne miejsca zajmują energia słoneczna i wodna. Większość badań nad odnawialnymi źródłami energii dotyczy nauk stosowanych. Ponadto wspieranie innowacji wspiera przejście do zrównoważonej energii. Badania naukowe nad bioenergią mają bardziej podstawowy charakter, niż badania odnoszące się do energii słonecznej i wodnej. Sugeruje to łatwy dostęp do zasobów i znaczące zaawansowanie badań nad bioenergią w Indonezji. Opracowanie indonezyjskiej polityki energetycznej, uwzględniającej odnawialne źródła energii i ich specyfikę, może zatem przyspieszyć transformację energetyczną, zgodną z ideą zrównoważonego rozwoju.

Słowa kluczowe: bibliometria, zrównoważona energia, Indonezja, polityka energetyczna

\section{Introduction}

Indonesia pledged at UN's COP 21 Paris Agreement to participate in the global scientific and political movement to combat climate change by maintaining the global average temperature below $2^{\circ} \mathrm{C}$ and even pursuing the necessary efforts further down to $1.5^{\circ} \mathrm{C}$. In the same time, the Government of Indonesia (GoI) is progressing to institutionalize the implementation of Sustainable Development Goals (SDGs) to support this green movement. GoI has set the national goal to include a $23 \%$ share of renewable energy (RE) in the total primary energy supply by 2025 . The target requires enormous efforts from the stakeholders in the energy sector, as the current total primary energy supply reached only 6\% by 2016 (REN21, 2018). Negro et al. (2012) and Rizzi et al. (2014) identify that policy interventions are important in fostering the role of scientific knowledge production in the energy transition by diffusing and implementing renewable energy technology (RET). On the other hand, scientific knowledge production influences the quality of public regulations (Costa et al., 2016; Desmarais et al., 2014). Policy design for scientific knowledge production on sustainable energy affects the production of scientific knowledge. The policy outcomes influence the quality of public regulation related RET.

Such a jump in the RE share from $7 \%$ to $23 \%$ in Indonesia will not be accomplished in the absence of integrated and transition strategies in form of public regulations. This includes the contributions of scientific knowledge from public and private sector. Private sector (industries) will then develop the knowledge to enable commercial technologies to penetrate the market in such a competitive way. Energy transition strategies are essential to protect both public and private interests on the energy sector, especially in emerging economic countries like Indonesia, where the flux of private capital is still important in developing infrastructures. Hence, technological innovation at the firm level (either public or private entities) is deemed important so that the country's goal for energy transition can be achieved at the national level. An understanding of the interactions between innovations and markets is critical, given the recent acceleration of energy market dynamics (Zweifel, Praktiknjo, \& Erdmann, 2017).
Kungl \& Geels (2018) concluded that German energy transition (Energiewende) caused industrial destabilization following the downfall of incumbent energy providers.

Scientific knowledge productions have been widely used to probe the trends and patterns of the scientific research and served as one of the inputs in the formulation of science policy for most OECD countries (Thomas, 1992). There is no doubt that the development of the new emerging scientific knowledge requires special attention to support the growth of scientific production in terms of funding or policy intervention (Leydesdorff et al., 1993; Leydesdorff \& Gauthier, 1996). Law et al. (1988) argued that science indicators are important tools for triggering scientific discussion, not cutting off or rationalizing particular preconceived positions, in the structure of policy making. Ultimately, policy makers benefit from using such observations regarding scientific capability when designing their policies.

Several studies on scientific knowledge productions on sustainable energy have been performed at the geographical or technological level or the combination of both. Rizzi et al. (2014) investigated the trends of the worldwide scientific production, finding that most of the OECD countries showed diversification approaches of RET, while most emerging economic countries showed a specialization approach of RET development. The paradox of choice based on socioeconomic situations determined how the country sets the pace through its energy policy. Manzano-Aguliaro et al. (2014) suggested that the availability of Renewable Energy Sources (RES) in one country did not positively influence the scientific knowledge production of a particular RET. At the EU level, at which its policy direction is regarded as the front runner in the supranational strategies and goals, Sanz-Casado et al. (2012) observed the impact of growth knowledge productions and wind generation. Furthermore, Celikatas et al. (2018) and Montoya et al. (2014) examine the growth of the scientific publications and citations in a country-specific case.

This paper is organized as follows: the paper is opened by providing an introduction regarding the importance of scientific knowledge productions in the sphere of the energy sector, Section 1 presents a general literature review on the sustainable energy, the country's energy landscape and regulatory 
framework, Section 2 explains the main research questions and method used in this paper, Section 3 provides the results and discussions, and Section 4 delivers the conclusions and policy implications.

\section{Literature review}

\subsection{Sustainable Energy in SDGs}

In 1987, the Bruntland Commission published Our Common Future as a report describing efforts to link various issues of economic development and environmental stability. The report defines the definition of sustainable development (SD), as development that meets the needs of the present without compromising the ability of future generations to meet their own needs. The United Nations Conference in 2012 introduced the concept of SD Goals (SDGs) to replace the concept of the Millennium Development Goals (MDGs) (Chopra et al., 2017). On September 25, 2015, the United Nations General Assembly has set 17 Sustainable Development Goals (SDG)s and 169 sub-goals to achieve the SD target by 2030. These goals and targets are to balance three dimensions of sustainable development: economic, social, and environment.

Ensure access to affordable, reliable, sustainable and modern energy for all is the goal of SDG7. Energy is a very important sector to obtain almost all SDGs. This is due to energy having a role to eradicate poverty through advances in health, education, water supply and industrialization, to combat climate change. This role is in electricity, heat, and transportation as an energy sector segmentation (Hillerbrand, 2018). Providing energy to meet today's needs without reducing the ability of future generations to meet their needs is the meaning of sustainable energy (SE). In this case, SE is a force that can be recharge during human life and does not cause long-term damage to the environment. RES are the scope of SE, such as hydroelectric power, biomass, geothermal, wind, waves, tidal and solar energy (Hollaway, 2013). Meanwhile, nuclear is considered not to be included as a SE, because of its radioactive waste (Hillerbrand, 2018). Some researchers claim that RE sources are the most efficient and effective solution to address current environmental problems that are faced and require potential long-term action for SD (Dincer, 2000; Lund, 2007; Sadorsky, 2011). The goal of SDG9 to promote sustainable industrialization, innovation, and infrastructure development is essential for the development of RET. The EU, for example, has been much progressing on SDG9 to increase the share of renewables by increasing their R\&D expenditures (Uğurlu, 2019). Thus, the practice of SE through the use of RE is a solution to achieve SDGs (Nerini et al, 2018).

\subsection{Energy landscape and its regulatory frame- works}

Fossil fuels dominate the focus of Indonesia's energy policy. The volatility of coal prices and on-going shale gas revolution provokes the question of the sustainability of Indonesia's energy policy based on exclusively on fossil fuels (Dutu, 2016). The challenging jump of RE share to meet the 2025 goal is real in the absence of a supportive regulatory environment and strong private investment. The government signed a contract to construct 68 renewable power plants from 2014 to December 2017 with a total generating capacity of 1,207 MW. The development capacity of the renewable power plant includes water (754 MW), biogas (17 MW), biomass (29 MW), solar (45 MW), geothermal (86 MW), and mini-hydro (276 MW) energy (MEMR, 2018). Based on information from the Ministry of Energy and Mineral Resources (MEMR, 2017), the realization of the electrification ratio for 2017 is $95.35 \%$. This exceeds the electrification ratio target for 2017, which is listed in the Strategic Plan of the MEMR at $92.75 \%$ (MEMR, 2017). With the increase in renewable energy (RE) generation capacity, it is expected to realize the electrification ratio target for 2018 (95.15\%) (Presidential Decree, 2017) and 2019 (99.9\%) (Presidential Decree, 2018).

In accordance with Law UU No. 30/2017, Law UU No. 30/2009, National Energy Policy (KEN), General Plan of National Energy (RUEN), and National Electricity General Plan 2008-2027 (RUKN), electric companies must prioritize the use of RE as the main energy source to supply electricity to rural areas that do not have basic electricity infrastructure, including remote villages, rural borders, and small inhabited islands. The development of RE and energy conservation is also the first priority of the program designed to meet the national priority for energy security (Presidential Decree, 2017). The increasing utilization of $\mathrm{RE}$ as a target in the priority of $\mathrm{RE}$ development programs is also listed in the Government Work Plan for 2019 (Presidential Decree, 2018). This means that $\mathrm{RE}$ is a priority in achieving energy security in Indonesia.

\subsection{Pushing the scientific knowledge productions}

A good governance framework requires high-quality regulations (Jacobzone et al., 2007). High-quality regulations are the regulations that obtain public policy objectives and apply minimal costs to communities, stakeholders, the environment and the state (Jacobzone et al., 2007). Thus, they provide the same benefits to traders and consumers, both domestic and foreign (Basedow et al., 2016). Thus, high-quality regulations require Good Regulatory Practices (GRP) to realize regulations that are conducive to international trade and economic integration in general (Basedow et al., 2016). For this reason, Asia-Pacific Economic Cooperation (APEC) - Organization for Economic Co-operation and Development (OECD) 
Table 1. Current public policy for scientific knowledge production on energies

\begin{tabular}{|c|c|c|c|c|c|c|}
\hline \multirow[t]{2}{*}{ Policy Strategy } & \multirow{2}{*}{$\begin{array}{c}\text { Government } \\
\text { Program }\end{array}$} & \multicolumn{5}{|c|}{ Upstream Specific Energy Technology } \\
\hline & & Generic & $\begin{array}{c}\text { Fossil- } \\
\text { Fuels }\end{array}$ & Nuclear & RE & Hybrid \\
\hline $\begin{array}{l}\text { R\&D and implemen- } \\
\text { tations of energy } \\
\text { technologies are di- } \\
\text { rected to support na- } \\
\text { tional energy indus- } \\
\text { tries }\end{array}$ & $\begin{array}{l}\text { Funding for } \\
\text { R\&D and im- } \\
\text { plementation of } \\
\text { energy technol- } \\
\text { ogies }\end{array}$ & $\bullet$ & & & & \\
\hline $\begin{array}{l}\text { Central government } \\
\text { and/or regional gov- } \\
\text { ernment drives the } \\
\text { establishment of the } \\
\text { supportive climate to } \\
\text { the use of R\&D re- } \\
\text { sults and implemen- } \\
\text { tations of energy } \\
\text { technologies at the } \\
\text { national level }\end{array}$ & $\begin{array}{l}\text { The increasing } \\
\text { use of the R\&D } \\
\text { results and im- } \\
\text { plementations } \\
\text { of energy tech- } \\
\text { nologies at the } \\
\text { national level }\end{array}$ & $\bullet$ & & & & \\
\hline $\begin{array}{l}\text { Central government } \\
\text { and/or regional gov- } \\
\text { ernment fortify } \\
\text { R\&D activities and } \\
\text { implementations of } \\
\text { energy technologies }\end{array}$ & $\begin{array}{l}\text { The increasing } \\
\text { R\&D activities, } \\
\text { mastery, and } \\
\text { implementa- } \\
\text { tions of energy } \\
\text { technologies }\end{array}$ & $\bullet$ & $\bullet$ & $\bullet$ & $\bullet$ & $\bullet$ \\
\hline
\end{tabular}

has published a checklist of regulatory reforms, where Regulatory Impact Analysis (RIA) is a tool for measuring or evaluating GRP (OECD, 2003). Desmarais et al. (2014) detected that several agencies throughout the United States (US) federal government were producing RIA based on using peerreviewed scientific research. Costa et al. (2016) also found that the use of scientific research in 101 RIA documents originating from 13 US government agencies during the period 2008-2012 played an important role in confirming public regulation. Therefore, scientific research plays an important role in designing policies thus pushing high-quality regulations in-place.

The importance of scientific research in sustainable energy has been recognized by the GoI in the National Research Master Plan (RIRN) and General National Energy Planning (RUEN). However, research and development (R\&D) activities and implementations of energy technologies are part of the supporting national policy sets, not main national policy sets. Fossil, RE, nuclear and hybrid energy is one of the priorities of the national $R \& D$ planning. The mandated R\&D on RE are geothermal, hydro, and biomass. Nuclear is not included as RE in accordance to the Law UU No. 30/2017.

Table 1 is recreated from the government regulation PP No. 22/2017 (RUEN) and shows that the specific technology related to the RE and hybrid is narrated only for the policy strategy to fortify R\&D activities and implementations. The generic term in the table indicates that the detailed program activities do not exclusively mention an upstream specific energy technology. Thus, the activities may target all spectrums of energy technology.

\section{Research question \& methodology}

\subsection{Research question}

The main research question in this study is thus: How does Indonesian scientific knowledge production on renewable energies successfully support the policy design for sustainable energy transition towards renewables?

This interdisciplinary research question stimulates future dialogue between Indonesia's scientific societies and policy makers to better position the national interest in light of sustainable energy transition to renewables. The scientometric indicators in this study demonstrate the national capacity for the scientific knowledge productions on sustainable energy - the first-ever study for Indonesia as of August 2019. The scientific publications used in this study are limited only to Indonesia's authors. We recognize the limitation that the authors might be financed by foreign R\&D funding, collaborate with the main authors from foreign countries as co-authors, or investigate the topic unrelated to Indonesia. For example, Sutrisno, Vennix, and Syaifudin (2015) investigate RES development in the Netherlands using the game's theory.

\subsection{Methodology}

To map the scientific knowledge productions, this study sourced the scientific publications from the databases of Web of Science (WoS). Being the world's oldest scientific literature database with high-quality scientific publications, the database has been used in many studies on scientific knowledge production (Boyle \& Sherman, 2006; Chadegani et al., 2013). In 
fact, the strong coverage of WoS in the area of natural and engineering sciences provides a better angle of attack for meeting the research objectives (Chavarro, Ràfols, \&Tang, 2018; Mongeon \& Paul-Hus, 2016; van Leeuwen, Moed, Tijssen, Visser, \& Van Raan, 2001).

We pulled the scientific publications for seven disciplines; six of them were specific RETs (geothermal, solar, wind, hydro, biofuel \& biomass, and hybrid), and energy policy and economics. The keywords for these areas are presented in Table 2. Rizzi et al. (2014) explored the extant journals for their scientometric research, limited to fourteen (14) natural and engineering science journals. In our study, there were no limitations regarding the discipline of journals, as we try also to outreach the scientific publication on the area of energy policy and economics which we consider important to construct the institutional setup in light of the successful embarkation of energy transition. We observe that there are 5,709 scientific papers published from 2000 to 2018.

Table 2. Keywords for extracting the data in seven disciplines

\begin{tabular}{|c|c|}
\hline Discipline & Key words \\
\hline $\begin{array}{l}\text { Geother- } \\
\text { mal }\end{array}$ & $\begin{array}{l}\text { (geothermal AND energy) OR (geother- } \\
\text { mal AND electricity) OR (geothermal } \\
\text { AND heating) OR (thermal AND water) }\end{array}$ \\
\hline Solar & $\begin{array}{l}\text { (solar AND energy) OR (solar AND } \\
\text { thermal AND energy) OR (solar AND } \\
\text { power AND photovoltaic*) OR (photo- } \\
\text { voltaic AND generator*) OR (photovol- } \\
\text { taic module*) OR (photovoltaic sys- } \\
\text { tem*) OR (solar cell*) OR (photovoltaic } \\
\text { cell*) OR (solar collector*) OR (photo- } \\
\text { voltaic collector*) OR (solar thermal } \\
\text { collector*) }\end{array}$ \\
\hline Wind & $\begin{array}{l}\text { (wind AND energy) OR (wind AND } \\
\text { power) OR (wind farm*) OR (wind } \\
\text { park*) OR (wind module*) OR (wind } \\
\text { turbine*) OR (wind generator*) OR } \\
\text { (wind AND turbine* AND generator*) } \\
\text { OR (wind AND offshore) OR (wind } \\
\text { AND onshore) }\end{array}$ \\
\hline Hydro & $\begin{array}{l}\text { (hydro AND energy) OR (hydro AND } \\
\text { power) OR (ocean AND energy) OR } \\
\text { (tidal AND energy) OR (hydro turbine*) } \\
\text { OR (hydroelectric*) OR (tidal AND } \\
\text { power*) OR (hydro AND generation*) } \\
\text { OR (water AND power) OR (wave AND } \\
\text { power) }\end{array}$ \\
\hline $\begin{array}{l}\text { Biofuel } \\
\& \\
\text { biomass }\end{array}$ & $\begin{array}{l}\text { (bio AND energy) OR (biomass AND } \\
\text { power) OR (bio*diesel) OR (waste AND } \\
\text { fuel) OR (waste AND alcohol*) OR } \\
\text { (waste AND gas) OR (waste AND en- } \\
\text { ergy) OR (biogas) OR (bioethanol) OR } \\
\text { (palm oil*) OR (soybean oil*) }\end{array}$ \\
\hline Hybrid & $\begin{array}{l}\text { (diesel OR storage) AND hybrid AND } \\
\text { renewable AND (power OR battery OR } \\
\text { solar OR wind OR hydro OR photovol- } \\
\text { taic* OR PV OR bio*) }\end{array}$ \\
\hline $\begin{array}{l}\text { Policy \& } \\
\text { economics }\end{array}$ & $\begin{array}{l}\text { renewable energy AND (policy OR } \\
\text { economy) }\end{array}$ \\
\hline
\end{tabular}

A free software tool, VOSviewer, was used to analyze the extracted data to produce a network visualization map based on the most often-occurring terms, the most often-occurring journals that cited the scientific publications, and the most often-occurring institutions that produced the scientific literatures (van Eck \& Waltman, 2010). We are interested to reveal the trends and patterns on scientific production on $\mathrm{RE}$ in Indonesia, given that this study focused on the policy implication of the production of scientific literatures on Indonesia's renewable energies.

The analysis produces a visualization map of the network of each attribute (occurred terms, co-citations, or institutions). For example, Fig. 3 is the visualization map of occurred terms on the scientific literatures. The often-occuring terms are, among the others, Indonesia, degree, property and structure. The map presents how the clusters of these attributes are placed and connected via lines representing groups of clusters. Attributes in the same cluster are displayed in the similar color. The connection line is displayed in the same color with the cluster, and the font size of the attribute represents the occurrence frequency. For example, the term structure and efficiency in Fig. 3 are displayed and connected in the blue color - meaning that both are in the same cluster. It implies that that most research discusses the term structure in parallel with efficiency. The clusters and network can be interpreted based on the research objectives. For example, Repanovici \& Nedulcu (2018) study the collaboration research on 3D printing using bibliometric networks and interpret the clusters of institutions as the collaborative group based on the geographical proximity. The study finds that Huazhong University of Science and Technology collaborates strongly with Tsinghua University, both in China, with other European universities.

\section{Results and discussions}

\subsection{High growth of total scientific publications with focused on applied knowledge}

This study observes the rapid growth of scientific publication on renewable energies starting in 2012 (Fig. 1). The average annual production in the period of 2012 to 2018 is twenty-seven (27) times higher than the average annual production in the period of 2000 to 2011 , respectively 766.14 and 28.83 scientific publications per year.

The first RUEN containing detailed policy strategies, government programs, and policy instruments for the national energy system was published in 2010. We suggest that the effect of the policy for scientific knowledge productions can be observed in 2012 by the sharp increase of Indonesia's annual scientific production on renewable energies. This time lag character through which the effect of the policy can be observed in the indicators are identified in various policy studies, thus suggesting that the lag is 


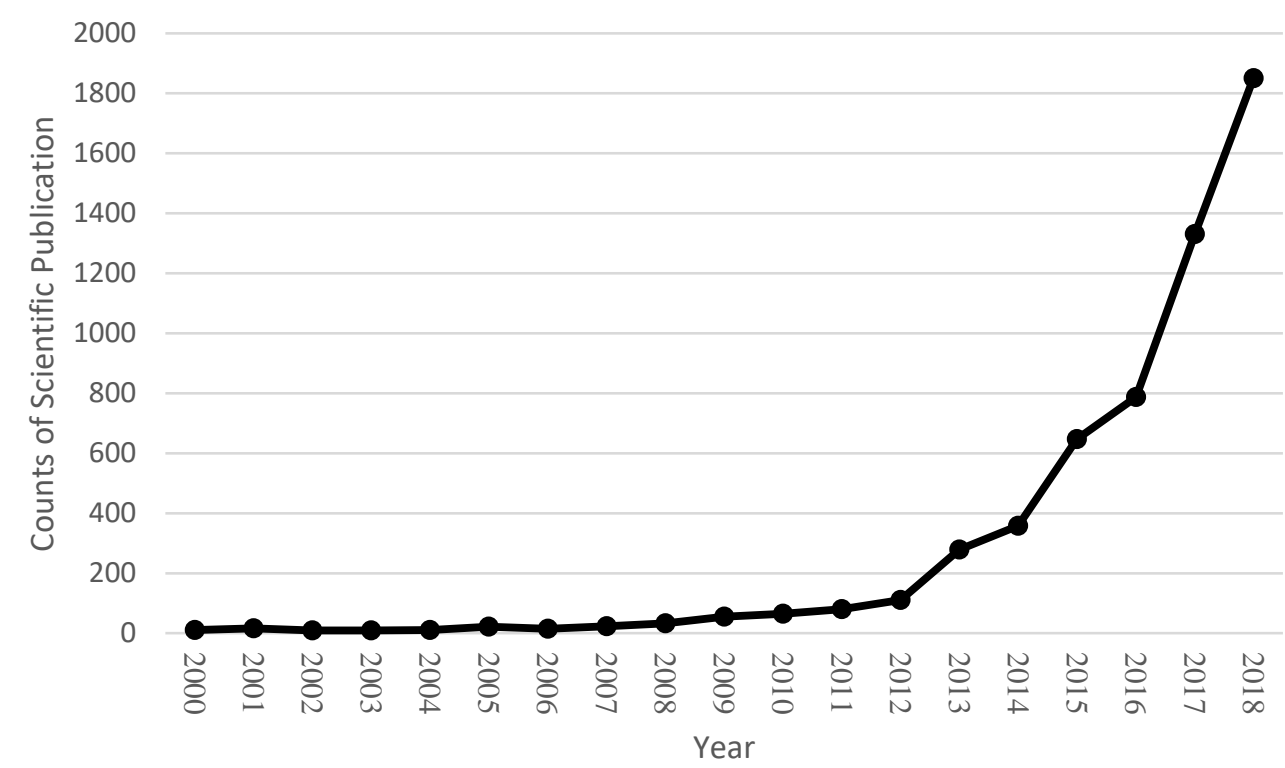

Figure 1. Aggregated RET scientific knowledge productions between 2000 and 2018.

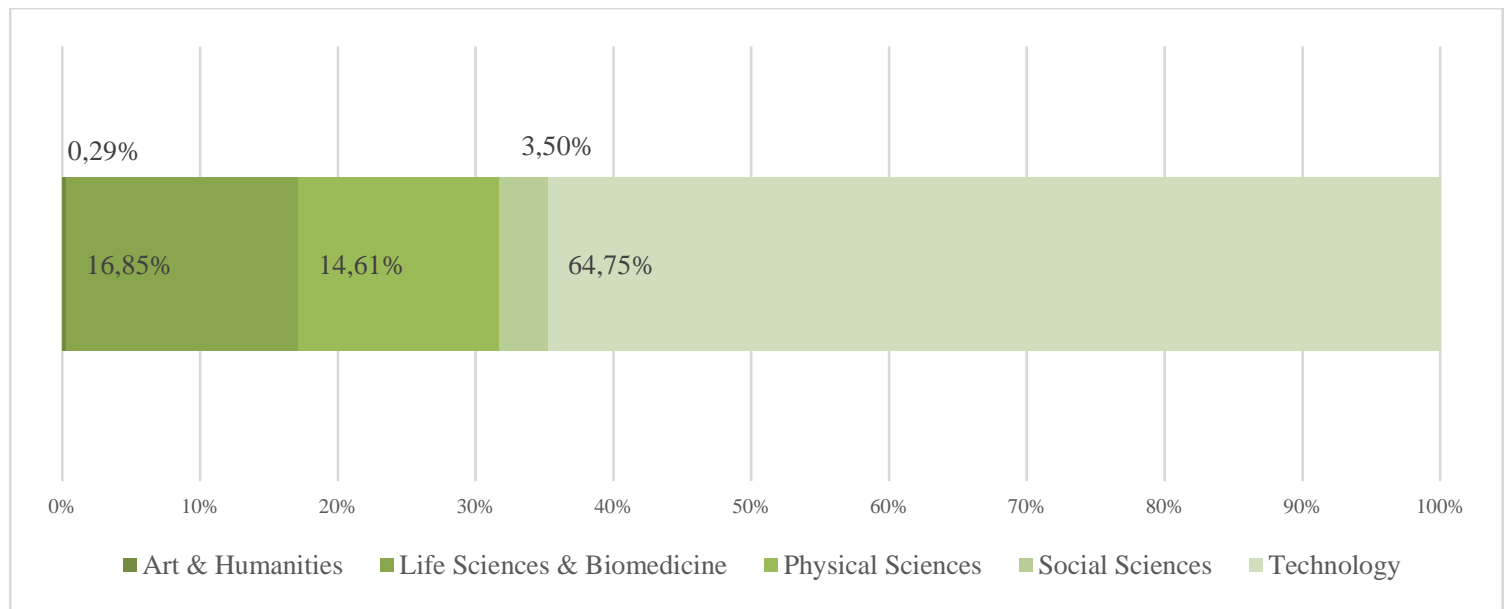

Figure 2. Category of journal that published the scientific production between 2000 and 2018.

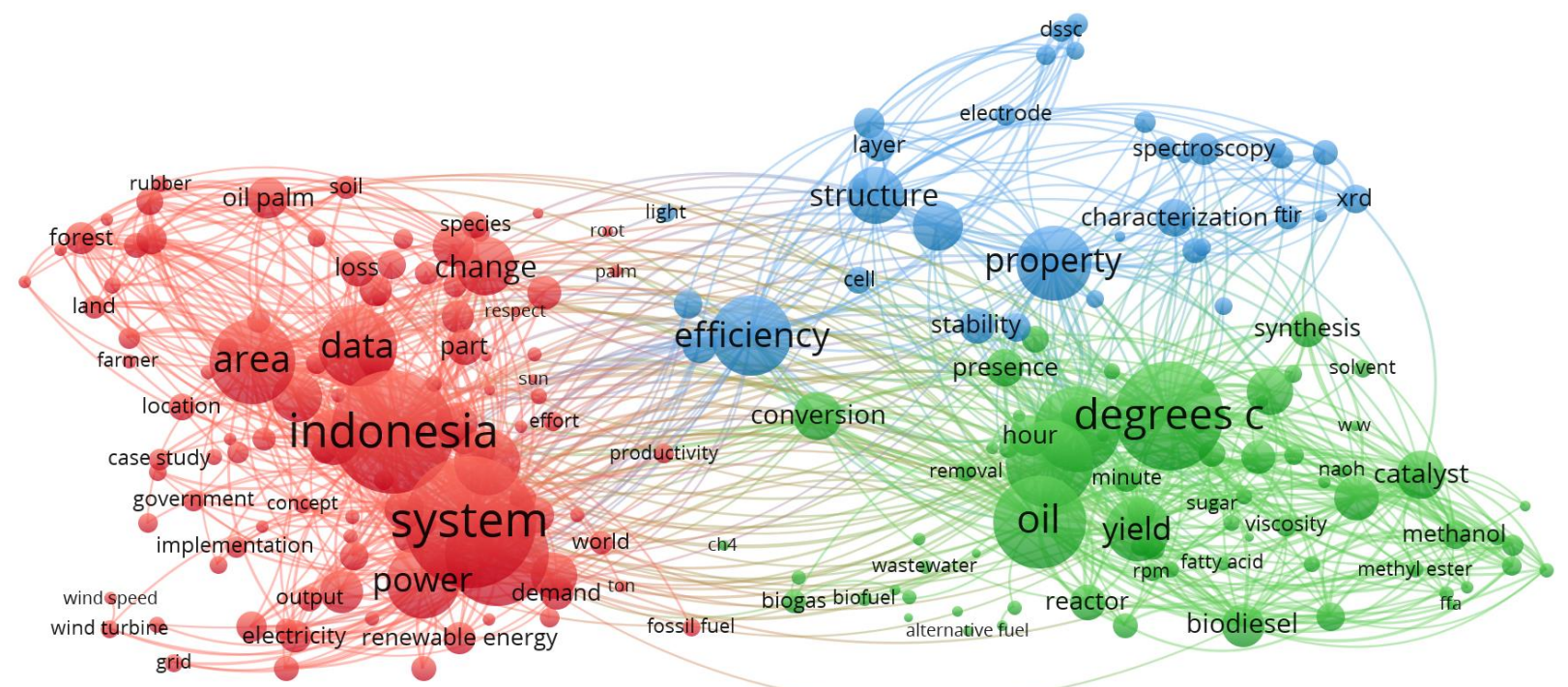

Figure 3. The network visualization for scientific knowledge productions on renewable energies between 2000 and 2018. 
between one to two years (Constantini et al., 2017; Lindman \& Söderholm, 2016).

We observe that most of Indonesia's scientific literatures belonged to the category of applied science (physical sciences and technology) journals, representing $79.36 \%$ of the total publications (Fig. 2). The rest are categorized as basic science (art \& humanities, life sciences \& biomedicine, and social sciences). This implies that the scientific knowledge production in Indonesia most often involves discussions of the mastery and implementation of RETs. However, the linkage between basic and applied knowledge is extremely meaningful to the innovative capability (Lundvall, 2016). The mismatch between basic and applied research is identified a systemic problem contributing to the poor innovative performance (OECD, 1997). This study suggests that Indonesia embarked on the energy transition by benefiting the innovation capability in applied knowledge. However, there is no scientific literature about Indonesia's RE innovation capability as of August 2019 that displays the contemporary innovation measurement such as R\&D expenditure, or the number of patents applied for or granted.

Using network visualization, we observe that there are three clusters within the scientific publications (Fig. 3). We identify that the first cluster is related to biofuel and biomass, with the most often-occurring terms as degree $\mathrm{C}$, oil, yield, and catalyst. The second cluster is recognized as the research themes on solar energy, with the most often-occurring terms being efficiency, property, structure, and characterization. All terms on both clusters are specific technologically related terms, even though we recognize that there may be overlap between the terms in one cluster or another. The remaining terms were clustered with most research themes in the power system and data processing to support the electricity generation from RES. The most often-occurring terms for this clusters are system, power, data, and area.

\subsection{Biofuels and biomass dominated the scientific knowledge productions}

Within 5,709 scientific papers published from 2000 to 2018, half of the research themes are biofuels and biomass $(52.90 \%)$, followed by solar $(16.85 \%)$, hydro (13.27\%), and geothermal (9.51\%) (Fig. 4). Our observation suggests that the research themes on biofuel and biomass are influenced by its relatively abundance resources (i.e. palm oil, paddy, sugar cane, corn, cassava, and wood waste) with estimation to produce the energy of 470 GJ per year (Dani $\&$ Wibawa, 2018). The research themes on bio energy are more often related to applied knowledge $(73.41 \%)$ than basic knowledge (26.59\%). However, the portion of basic research on solar and hydro energy is indeed smaller than that on bio energy, respectively $10.53 \%$ and $13.64 \%$. This suggested that the capability for basic knowledge production on bio energy is higher than that on solar and hydro. Again, the abundance resources of biofuel and biomass in Indonesia provide greater access for researchers than on solar and hydro, for which there are more significant up-front costs for the physical infrastructure development (materials, laboratories, and testing equipment). Biofuel and biomass have been long regarded as substantial pre-industrial energy sources, given that nature freely offers woody plants and rivers (Zweifel, Praktiknjo, \& Erdmann, 2017).

Co-citation is used to probe the scientific knowledge transfer across disciplines (Trujillo \& Long, 2018). We are interested in assessing whether the research insights from different disciplines are being used by one another. Disciplinary siloes may present and lead to partial or full failures to draw conclusions of the research question (Stuckler, 2015). Our study identifies that most of Indonesia's scientific knowledge productions are from Bioresource Technology, with 2,808 co-citations (Fig. 5). This category is followed by Renewable Sustainable Energy Review (2,018 co-citations) and Fuel (1,374 co-citations). We recognize that there are 5 visible clusters of the co-citations in bio-energy, sustainable energy, energy physics, energy for fuel, and energy chemistry. Our study did not find any weak co-citation links for any cluster. Even the scientific production on the area of policy and economics were co-cited by different clusters.

\subsection{Limited focus on the area of policy and econom- ics and hybrid systems}

The presence of the research on public policy and business economics is important, given that there are firms seeking profits that construct and operate the RES power stations. The business climate must be tuned to support a large-scale deployment of RET. Tailor-made policy instruments should be identified, especially regarding specific technology, as Negro et al. (2012) argued regarding the necessity of specific policy measures on specific technological systems to accelerate the diffusion of knowledge on renewable energies. We identify a lack of research themes on policy and economics for renewable energies. 73 scientific publications are found from 2000 to 2018 with a significant raise on 2018 (Fig. 6). Most policy and economics studies in this regard examine national level issues and problems on RE development using descriptive method $(50.68 \%)$. The attractiveness of biomass and biogas to replace fossil fuels in Indonesia's energy system is widely acknowledged but requires a more mission-oriented strategies at the national level (Bunyamin \& Purnomo, 2017; Mulyana, Fitriani, Saad \& Yuliah, 2017; Sukirman, 2018; Sommeng \& Anditya, 2018; Rosyidi, BoleRentel, Lesmana \& Ikhsan, 2013; Wahyudi, Kurnani, \& Clancy, 2015). Other studies use empirical method to draw conclusion at macro- and microeconomics level $(45.21 \%)$ and the descriptive me- 


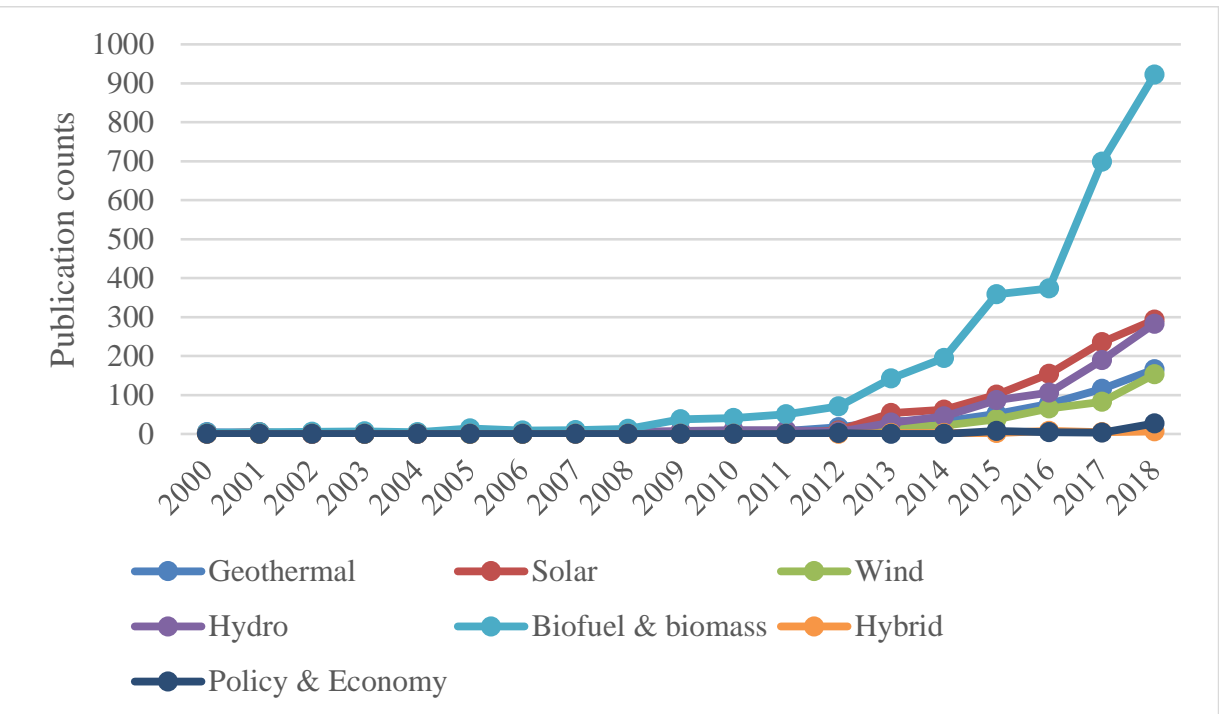

Figure 4. The distribution of scientific production per technologies between 2000 and 2018.

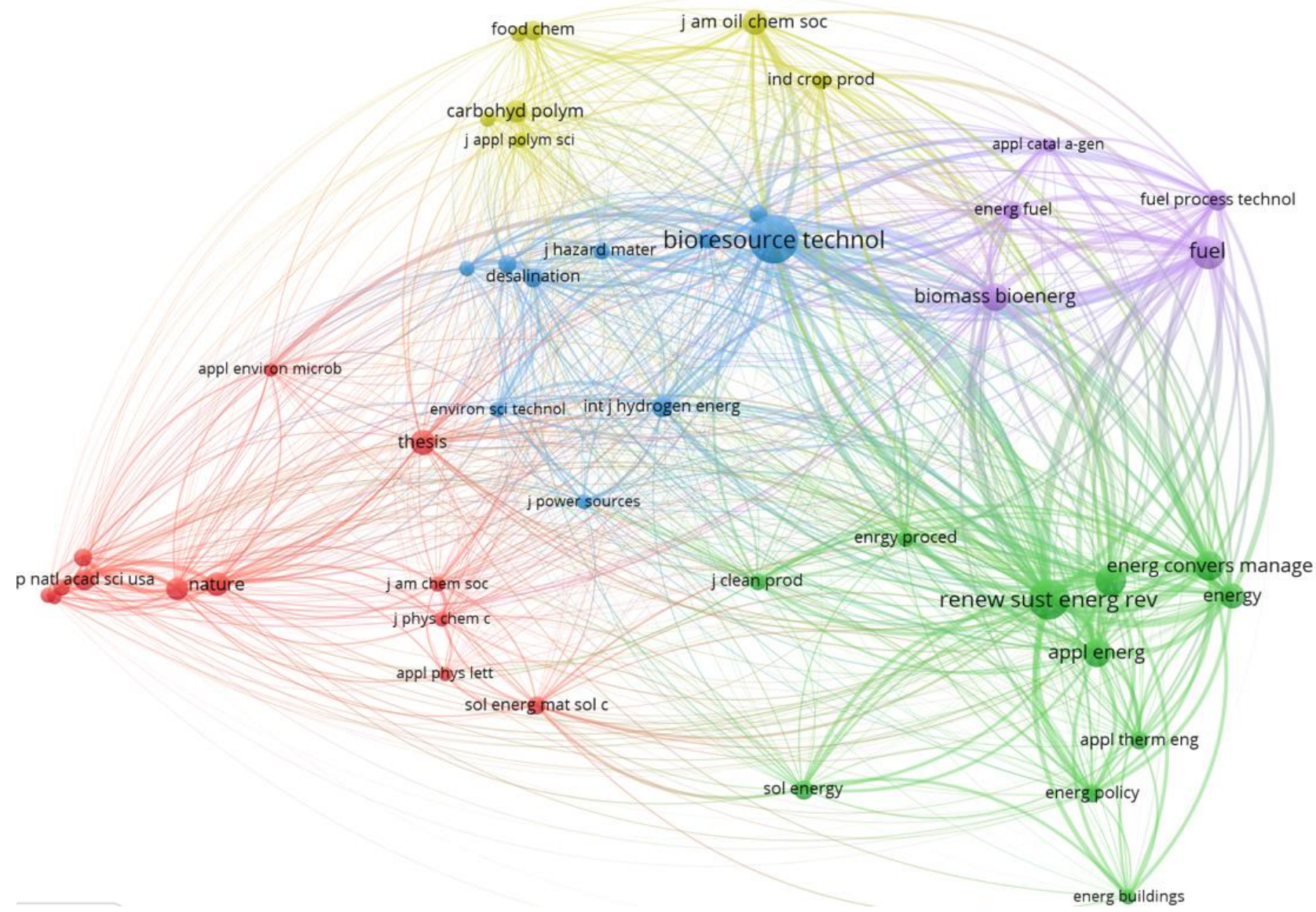

Figure 5. The co-citations for the scientific production from 2000 to 2018.

thod for deploying RE system at sectoral level $(4.11 \%)$.

While hybrid systems are important for energy transitions, our study observes only 19 scientific publications on hybrid systems (Fig. 6). Hybrid systems have been regarded as one of the technological solutions in the narration of energy transition in Indonesia. Although there is no modular definition of hy- brid systems, it is inevitable that diesel-solar PV systems may provide lower Cost of Energy (COE) when the GoI dismantles diesel subsidies (Arisaktiwardhana \& Akbar, 2018). Such hybrid systems, combining fossil fuel and renewable sources, are deemed important to decrease the COE (Ismail, Moghavvemi, Mahlia, Muttaqi \& Moghavvemi, 2015) and reduce the carbon emission in the current 


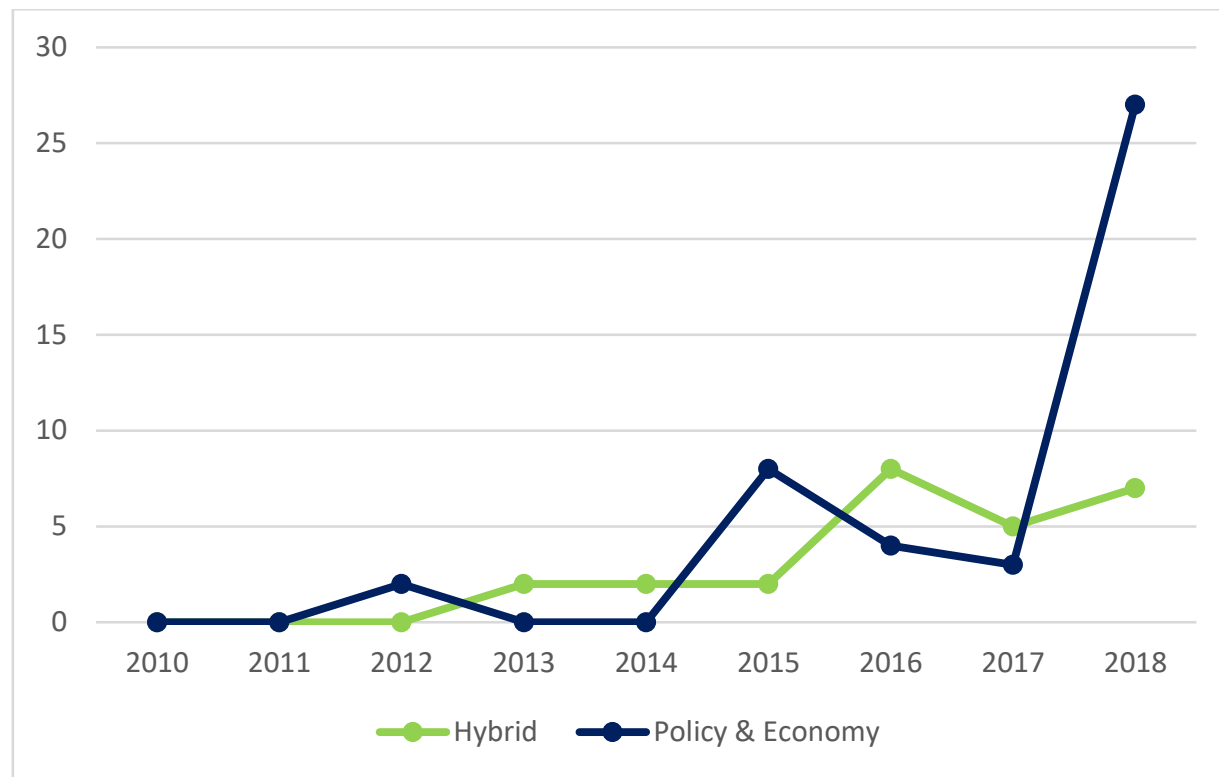

Figure 6. The scientific production for policy \& economics and hybrid systems from 2000 to 2018.

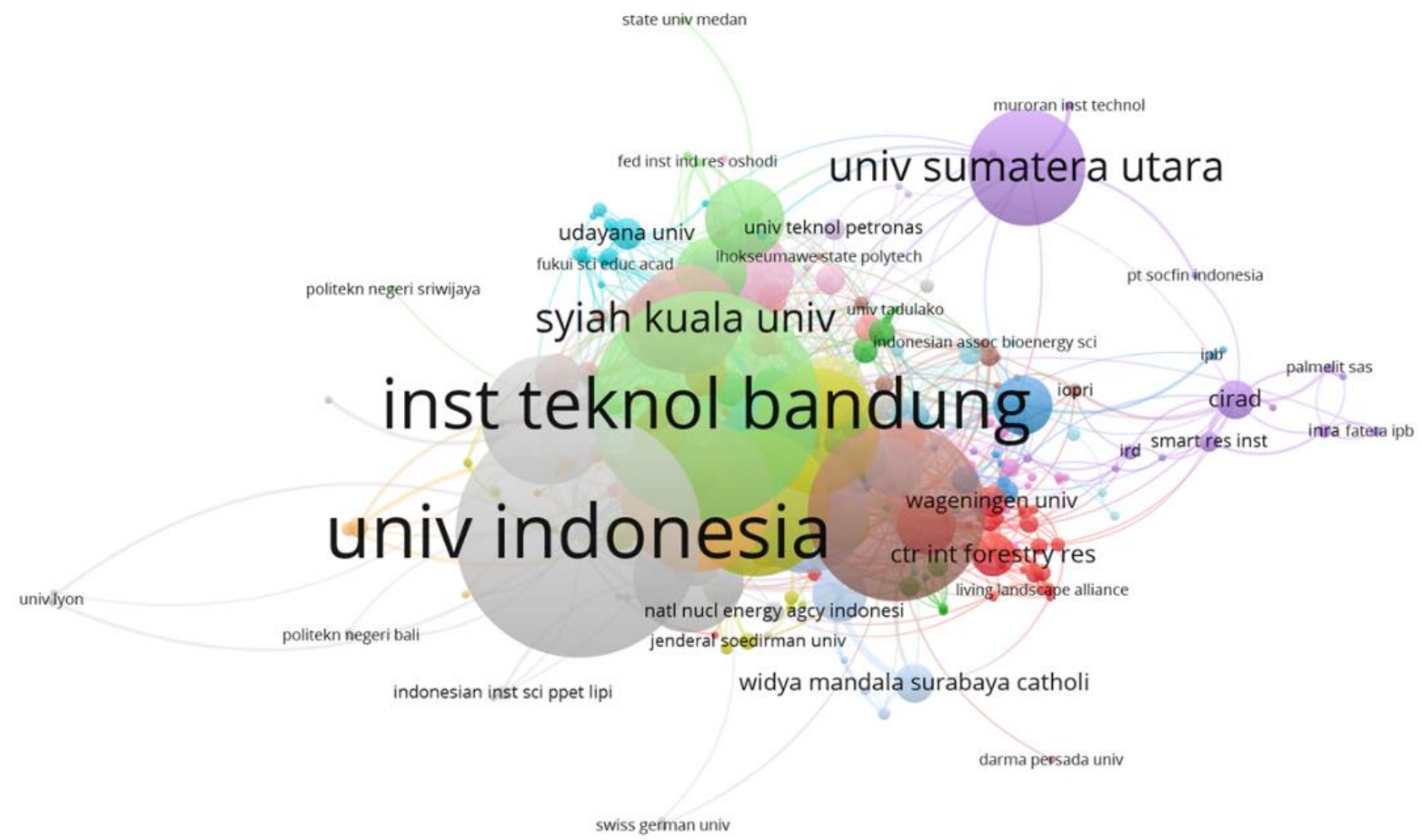

Figure 7. The network visualization for the institutions producing scientific production on renewable energies from 2000 to 2018.

energy system (Faanzir, Soedibyo \& Ashari, 2017). We identify that most studies are related to the implementation of the hybrid systems for the isolated off-grid areas $(42.31 \%)$. For example, the hybrid system in Labuan Bajo (Nizam \& Wicaksono, 2018), in Miangas Island (Rumbayan \& Nagasaka, 2018), Papua (Ardin, Rahardjo, \& Hudaya, 2017), Sebira Island (Wicaksana, Muslim, Hutapea, Purwadi, \& Haroen, 2016), or East Sumba (Mehang, Tanoto, \& Santoso, 2016). Most hybrid systems are the combination of diesel-solar PV. Other scientific studies were related to the on-grid systems $(30.77 \%)$ and the off-grid systems in the commercial and industries areas $(23.08 \%)$.

\subsection{Actors behind the scientific knowledge produc-} tions on renewable energies

A total of more than 300 different universities and research institutions contributed to the scientific knowledge productions on renewable energies in Indonesia. The five (5) top Indonesian universities and research institutions were Institut Teknologi Ban- 
dung (11.53\%), Universitas Gadjah Mada (8.89\%), Universitas Indonesia (8.60\%), Institut Pertanian Bogor $(5.83 \%)$, and Institut Teknologi Sepuluh November (3.91\%) (Fig. 7). The network visualization map recognizes several clusters regarding the universities and research institutions behind the scientific knowledge productions on renewable energies. We identify several cluster leaders with high publication productions: Institut Teknologi Bandung with solar, hydro, and geothermal energy; Institut Pertanian Bogor with biofuel and biomass; and Institut Teknologi Sepuluh November with wind energy. Universitas Indonesia leads the cluster, with even distribution of the scientific knowledge productions on all renewable energies. It is worth noting that Universitas Sumatera Utara $(3.55 \%)$ is among the most active Indonesian universities in the knowledge productions on biofuel and biomass.

We recognize that a number of collaborations takes place within the international society (universities and research institutions). Malaysia, Germany and Australia are among the top foreign countries with high interest in collaborating with Indonesian scientists. The geographical and historical proximity between Indonesia and these countries push forward the international collaboration. The top seven (7) foreign universities or research institutes were Universitas Malaysia (2.49\%), Universitas Sains Malaysia (2.25\%), Universitas Putra Malaysia (1.97\%), Universitas Kebangsaan Malaysia (1.96\%), Universitas Teknologi Malaysia (1.76\%), University of Queensland Australia (1.68 \%), and Universitaet Gottingen Germany (1.61\%).

\section{Conclusions \& policy implications}

Using the data from WoS, this study observed a total of 5,709 Indonesia's scientific literatures on sustainable energy between 2000 and 2018. Nuclear is excluded due the regulatory and contemporary view on renewable energies. The study reveals a significant growth on the scientific production since 2012. The increased growth is a result of different $R \& D$ policy sets and compensation structure for senior academic members (Rochmyaningsih, 2018). The analysis reveals that most scientific production in Indonesia are in the area of bio energy, in which there are abundance resources of biofuel and biomass throughout the country. This suggests a positive influence of the availability of the specific energy resources for scientific production in Indonesia - not like what have been identified by Manzano-Aguliaro et al. (2014). We argue that the up-front infrastructure costs for investigating bio energy is lower than that of any other sustainable energies in Indonesia.

Most scientific production on RE is related to applied knowledge. This suggests that, from the innovation perspective, the patterns of research in Indonesia represents the innovation mode of technology modifiers and technology adapters. Our study reveals no weak co-citation links for policy and economics, despite their low scientific production, to other RETs. There is clear evidence of knowledge transfer on renewable energy from science and technology to the policy and economics. Hybrid systems to solve the problem of low rates of RET development is not yet the focus of the research in Indonesia. Our study reveals that most scientific publications on hybrid systems discussed the implementation for offgrid and isolated areas. These findings support our argument that hybrid systems are essential for energy transition where the lack of energy access is identified. Prioritizing renewable energy in the main national policy sets can align the sense of urgency with $\mathrm{R} \& \mathrm{D}$, thus promoting the implementation of SDG7 and SDG9 in Indonesia.

Our study identifies that Indonesian universities have remarkably led and collaborated in the research on RET. However, policies to establishing a research cluster for a specific technology in conjunction with the priority of RET can successfully deliver the national R\&D strategic goals and boost the existing national and international collaborations. The research cluster can increase the national competitiveness and act as a single point of contact to disseminate the existing applied scientific knowledge to the industries. Thus, both academia and industries can promote sustainable energies in Indonesia for the long run.

We acknowledge that our study is mainly carried out using the searching queries that may induce confirmation bias and limit the searching results. Further research on the interaction between Indonesia RE R\&D spending, innovation output (patenting activities), knowledge spills-over, and collaboration may shed light on the dynamics of the national innovation system in accelerating the sustainable energy transition. It can also reflect the progress of SDGs related to affordable energy and innovation. Linking the analysis to the institutional setup (i.e. policy strategies, policy instruments) may increase the interdisciplinary understanding on this intradisciplinary topic.

\section{References}

1. ARDIN F., RAHARDJO A. \& HUDAYA C., 2017, Electricity Price and Subsidy Scenario for Hybrid Power Generations on Off-Grid System, in: International Conference on Control, Electronics, Renewable Energy, and Communication, p. 132-188.

2. ARISAKTIWARDHANA, D., \& AKBAR, I., 2018, Reducing Economic Disparity in the Outermost and Border Regions: Assessing Barriers and Opportunities in the Electricity Sector. The $3^{\text {rd }}$ International Conference on Energy, Environmental and Information System (ICENIS 2018), E3S Web Conf., Volume, 73, 01001.

3. ASIA-PACIFIC ECONOMIC COOPERATION (APEC) - ORGANISATION FOR ECONOMIC COOPERATION AND DEVELOPMENT (OECD), 
2003, APEC-OECD Integrated Checklist on Regulatory Reform, OECD Publishing, Paris.

4. BARLOW P., MCKEE M., BASU S., STUCKLER D., 2017, The health impact of trade and investment agreement: a quantitative systematic review and network co-citation analysis, in: Globalization and Health, vol. 13, p. 1-13.

5. BASEDOW R., KAUFFMANN C., 2016, International Trade and Good Regulatory Practices: Assessing the Trade Impacts of Regulation, OECD Regulatory Policy Working Papers. No. 4, OECD Publishing, Paris.

6. BOYLE F., SHERMAN D., 2006, Scopus: The product and its development, in: The Serials Librarian, 49(3), p. 147-153.

7. BUNYAMIN A., PURNOMO D., 2017, Biomass potential resources identification in Togean Islands, Central Sulawesi, in: IOP Conference Series-Earth and Environmental Science, 65.

8. CHAVARRO D., RÀFOLS I., TANG P., 2018, To what extent is inclusion in the Web of Science an indicator of journal 'quality'?, in: Research Evaluation, 27(2), p. 106-118.

9. CHADEGANI A. A., SALEHI H., MD. YUNUS M., FARHADI H., FOOLADI M., FARHADI M., EBRAHIM N. A., 2013, A Comparison between Two Main Academic Literature Collections: Web of Science and Scopus Databases, in: Asian Social Science, 9(5), p. 18-26.

10. CHOPRA S., VIRMANI M., 2017, MDG's to SDG 's: A necessary shift, in: International Journal of Applied Research, 3(6), p. 836-839.

11. CELIKATAS M. S., SEVGILI T., KOCAR G., 2018, A snapshot of renewable energy research in Tukey, in: Renewable Energy, 34, p. 1479-1486.

12. COSTA M., DESMARAIS B.A., HIRD J.A., 2016, Science Use in Regulatory Impact Analysis: The Effects of Political Attention and Controversy, in: Review of Policy Research, 33(3), p. 251-259.

13. COSTANTINI V., CRESPI F., PALMA A., 2017, Characterizing the policy mix and its impact on ecoinnovation: A patent analysis of energy efficient technologies, in: Research Policy, 46, p. 799-819.

14. DANI S., WIBAWA A., 2018, Challenges and policy for biomass energy in Indonesia, in: International Journal of Business, Economics, and Law, 15(5), p. 41-47.

15. DESMARAIS B.A., HIRD J.A., 2014, Public policy's bibliography: The use of research in US regulatory impact analyses, in: Regulation \& Governance, 8(4), p. 497-510.

16. DINCER I., 2000, Renewable energy and sustainable development: A crucial review, in: Renewable and Sustainable Energy Reviews, 4(2), p. 157-175.

17. DUTU R., 2016, Challenges and policies in Indonesia's energy sector., in: Energy Policy, 98, p. 513519.

18. FAANZIR S., ANSHARI M., 2017, Emission abatement cost analysis of hybrid marine current/photovoltaic/diesel system operation, presented at: 2017 International Seminar on Application for Technology of Information and Communication.

19. GRUBB M., 2014, Planetary economics: energy, climate change and the three domains of sustainable development, Routledge, New York.

20. HILLERBRAND R., 2018, Why Affordable Clean Energy Is Not Enough. A Capability Perspective on the Sustainable Development Goals, in: Sustainability, 10, 2485.

21. HOLLAWAY L.C., 2013, Sustainable Energy Production: Key Material Requirements, in: From standards to quality infrastructure: a review of impact studies and an outlook, ed. Bai J., Advanced FibreReinforced Polymer (FRP) Composites for Structural Applications, Woodhead Publishing Limited, United Kingdom.

22. ISMAIL M.S., MOGHAVVEMI M., MAHLIA T.M.I., MUTTAQI K.M., MOGHAVVEMI S., 2015, Effective utilization of excess energy in standalone hybrid renewable energy systems for improving comfort ability and reducing cost of energy: A review and analysis, in: Renewable \& Sustainable Energy Reviews, 42, p. 726-734.

23. JACOBZONE S., CHOI C., MIGUET C., 2007, Indicators of Regulatory Management Systems, in: OECD Working Papers on Public Governance, OECD Publishing, Paris.

24. LAW J., BAUIN S., COURTIAL J. P., WHITTAKER J., 1988, Policy and the mapping of scientific change: a co-word analysis of research into environmental acidification, in Scientometrics, 14(3-4), p. 251-264.

25. LINDMAN Å. \& SÖDERHOLM P., 2016, Wind Energy and Green Economy in Europe: Measuring Policy-induced Innovation Using Patent Data, in: Applied Energy, 176, p. 1351-1359.

26. LEYDESDORFF L., COZZENS S., VAN DER BESSELAAR P., 1993, Tracking areas of strategic importance using scientometrics journal mappings, in: Research Policy, 23, p. 217-229.

27. LEYDESDORFF L., GAUTHIER E., 1996, The evaluation of national performance in selected priority areas using scientometrics methods, in: Research Policy, 25, p. 431-450.

28. LUND H., 2007, Renewable energy strategies for sustainable development, in: Energy, 32(6), p. 912919.

29. KUNGL G., GEELS F. W., 2018, Sequence and alignment of external pressures in industry destabilization: understanding the downfall of incumbent utilities in the German energy transition, in: Environmental Innovation and Societal Transition, 26, p. 78100.

30. MANZANO-AGUGLIARO F., ALCAYDE A., MONTOYA F. G., ZAPATA-SIERRA A., GIL C., 2013, Scientific production of renewable energies worldwide: An overview, in: Renewable and Sustainable Energy Reviews, 18, p. 134-143.

31. MEHANG T.S., TANOTO Y., SANTOSO M., 2016, Potential of Small Size Hybrid Diesel-Photovoltaic to Improve Sub-District Supply Duration in East Sumba, Indonesia, in: International Journal of Renewable Energy Research, 6(3), p. 964-969.

32. MINISTRY OF ENERGY AND MINERAL RESOURCES (MEMR), 2017, https://www.esdm.go.id/ assets/media/content/content-rasio-elektrifikasi.pdf (05.06.2018)

33. MINISTRY OF ENERGY AND MINERAL RESOURCES (MEMR), 2018, http://km.reddplusid.org /d/006c64491cb8acf2092ce0e0341797fe (05.06.2018).

34. MONGEON P., PAUL-HUS A., 2016, The journal coverage of Web of Science and Scopus: a comparative analysis, in: Scientometrics, 106(1), p. 213-228. 
35. MONTOYA F. G., MONTOYA M. G., GÓMEZ J., MANZANO-AGUGLIARO F., ALAMEDA-HERNÁNDEZ E., 2014, The research on energy in spain: A scientometric approach, in: Renewable and Sustainable Energy Reviews, 29, p. 173-183.

36. MULYANA C., FITRIANI N.I., SAAD A., YULIAH Y., 2017, Empowerment model of biomass in west java, in: IOP Conference Series-Earth and Environmental Science, no. 65.

37. NEGRO S. O., ALKEMADE F., HEKKERT M. P., 2012, Why does renewable energy diffuse so slowly? A review of innovation system problems, in: Renewable and Sustainable Energy Reviews, 16, p. 38363846.

38. NERINI F.S., TOMEI J., TO L.S., BISAGA I., PARIKH P., BLACK M., BORRION A., SPATARU C., BROTO V. C., ANANDARAJAH G., MILLIGAN B., MULUGETTA Y., 2018, Mapping synergies and trade-offs between energy and the Sustainable Development Goals, in: Nature Energy, 3, p. 1015 .

39. NIZAM M., WICAKSONO F.X.R., 2018, Design and Optimization of Solar, Wind, and Distributed Energy Resource (DER) Hybrid Power Plant for Electric Vehicle (EV) Charging Station in Rural Area, in: $5^{\text {th }}$ International Conference on Electric Vehicular Technology (ICEVT), p. 41-45.

40. OECD, 1997, http://www.oecd.org/science/inno/ 2101733.pdf (05.06.2018).

41. PRESIDENTIAL DECREE (PP) NO. 22 YEAR 2017, 2017, National Energy Planning, The Secretary Cabinet of the Republic of Indonesia, Jakarta.

42. PRESIDENTIAL DECREE (PP) NO. 79 YEAR 2017, 2017, Government Work Plans for 2018, The Secretary Cabinet of the Republic of Indonesia, Jakarta.

43. PRESIDENTIAL DECREE (PP) NO. 72 YEAR 2018, 2018, Government Work Plans for 2019, The Secretary Cabinet of the Republic of Indonesia, Jakarta.

44. REPANOVICI R.M., NEDELCU, 2018, 3D printing new direction and collaboration in scientific research. A scientometric study using Web of Science, Clarivate Analytics database, in: MATEC Web of Conferences, no. 178.

45. RISTEKDIKTI, 2017, http://rirn.ristekdikti.go.id (05.06.2018).

46. REN21, 2018, Renewable 2018: Global Status Report, REN21 Secretariat, Paris.

47. RIZZI F., VAN ECK N. J., FREY M., 2014, The production of scientific knowledge on renewable energies: Worldwide trends, dynamics and challenges and implications for management, in: Renewable Energy, 62, p. 657-671.

48. ROSYIDI A.P., BOLE-RENTEL T., LESMANA S.B., IKHSAN J., 2014, Lessons Learnt from the Energy Needs Assessment carried out for the Biogas Program for Rural Development in Yogyakarta, Indonesia, in Procedia Environmental Sciences, 20, p. 20-29.

49. ROCHMYANINGSIH D., 2018, How to shine in Indonesian science? Game the system. in: Science, 363(6423), p. 111-112.
50. RUMBAYAN M., NAGASAKA K., 2018, Techno Economical Study of PV-Diesel Power System for a Remote Island in Indonesia: A Case Study of Miangas Island, in: $8^{\text {th }}$ International Conference on $\mathrm{Fu}$ ture Environment and Energy, no 150.

51. SADORSKY P., 2011, Some future scenarios for renewable energy, in: Futures, 43(10), p. 1091-1104.

52. SANZ-CANSADO E., GARCIA-ZORITA J. C., SERRANO-LÓPEZ A. E., LARSEN B., INGWERSEN P., 2012, Renewable energy research 1995-2009: a case study of wind power research in EU, Spain, Germany and Denmark, in Scientometrics, 95, p. 197-224.

53. STUCKLER D., REEVES A., KARANIKOLOS M., MCKEE M., 2015, The health effects of the global financial crisis: Can We reconcile the differing views? a network analysis of literature across disciplines, in: Health, Economy Policy, and Law, 10(1), p. 83-99.

54. SUKIRMAN Y.A., 2018, Developing a green lending model for renewable energy project (case study electricity from biogas fuel at Palm Oil Industry), in: $I O P$ Conference Series-Earth and Environmental Science, no. 131.

55. SUTRISNO A., VENNIX J.A.M., SYAIFUDIN N., 2015, Improving Renewable Energy Transition Acceptance: A Simulation Gaming Approach on a Multi Actor Setting in the Netherlands, in: Makara Journal of Technology, 19(3), p. 103-112.

56. SOMMENG A.N., ANDITYA C., 2018, Boosting renewable power generation in Indonesia electricity sector: a policy action by the government, in: $E 3 S$ Web of Conferences, no. 67.

57. TRUJILLO C. M., LONG T. M., 2018, Document cocitation analysis to enhance transdisciplinary research, in: Science Advances, 4(1), p. 1-9.

58. UĞURLU E., 2019, Renewable Energy Strategies for Sustainable Development in the European Union, in: Renewable Energy, eds. Kurochkin D., Shabliy E., Shittu E., Palgrave Macmillan, Cham.

59. VAN ECK N. J., WALTMAN L., 2010, Software survey: VOSviewer, a computer program for bibliometric mapping, in: Scientometrics, 84, p. 523-538.

60. VAN LEEUWEN T. N., MOED H. F., TIJSSEN R. J. W., VISSER M. S., VAN RAAN A. F. J., 2001, Language biases in the coverage of the Science Citation Index and its consequences for international comparisons of national research performance, in: Scientometrics, 51(1), p. 335-346.

61. WAHYUDI J., KURNANI T.B.A., CLANCY J., 2015, Biogas Production in Dairy Farming in Indonesia: A Challenge for Sustainability, in: International Journal of Renewable Energy Development, 4(3), p. 20-29.

62. WICAKSANA H., MUSLIM M.M., HUTAPEA S.F., PURWADI A., HAROEN Y., 2016, Design, Implementation and Techno-Economic Analysis of Hybrid PV-Diesel for Off-Grid System in Sebira Island, in: $3^{\text {rd }}$ Conference on Power Engineering and Renewable Energy, p. 39-44.

63. ZWEIFEL P., PRAKTIKNJO A., ERDMANN G., 2017, Energy economics: theory and applications, Springer, Berlin. 